\title{
HOW DIFFERENT ARE TREATIES AND MODERN CUSTOMARY INTERNATIONAL LAW? A RESPONSE TO VERDIER AND VOETEN
}

\author{
Timothy Meyer*
}

Anthony D'Amato wrote in his 1971 The Concept of Custom in International Law" that "[t]he only way customary international law can change ... is by giving legal effect to departures from preceding customary norms." Violations are the seeds of new customary rules. International relations theory also teaches us that as the shadow of the future grows longer, states may forego short-term benefits from cheating on their legal obligations in order to preserve long-term cooperation. In "Precedent, Compliance, and Change in Customary International Law," Pierre-Hugues Verdier and Erik Voeten combine these two insights to argue that "a state may comply [with a customary rule] because it knows its decision to defect creates a precedent that may undermine a cooperative norm it values."

This essay asks whether treaties are any different. In my view, scholars tend to overstate the differences between how customary international law (CIL) and treaties operate in the modern world. Treaties and CIL are indeed importantly different as lawmaking processes, but they are not so different with regard to compliance and enforcement. Nor is the role of state practice the most important distinction between how treaties and custom are created and changed over time. Rather, treaty-making differs from custom in that it permits a set of exclusion and agenda-control devices that are unavailable in the relatively decentralized world of custom.

Verdier and Voeten's article squarely raises the question of how custom and treaties differ. They argue that an interest in not undermining a valuable legal rule is especially important in promoting compliance with custom, as opposed to international agreements. Unlike treaties, they assert, CIL "does little to facilitate reciprocal or retaliatory punishment strategies." 3 For example, in their view CIL rules are not supported by dispute resolution mechanisms and do not contain flexibility clauses often found in treaties. Moreover, CIL applies to all states, whereas treaties apply only to states that consent. For this reason, Verdier and Voeten believe that CIL cannot be supported by " "tit-for-tat' equilibria based on direct reciprocity." ${ }^{4}$ Rather, the precedential incentive to comply with rules steps in to fill what Verdier and Voeten view as the gap in incentives to comply with custom left by the weakness of direct reciprocity, retaliation, and to a lesser extent reputation.

Verdier and Voeten's basic insight - that states may avoid violating customary rules in situations in which they both value the rule and worry that their cheating may lead to the rule's erosion-is a critical and im-

* Associate Professor of Law at the University of Georgia School of Law.

Originally published online 5 Apr. 2015.

1 Anthony A. D’Amato, The Concept of Custom in International LaW (1971).

2 Pierre-Hugues Verdier \& Erik Voeten, Precedent, Compliance, and Change in Customary International Law: An Explanatory Theory, 108 AJIL 389, 390 (2014).

${ }^{3} \underline{I d}$.

${ }^{4} \underline{I d}$. 
portant one. The possibility that opportunistic behavior today will destabilize cooperation tomorrow by disrupting existing expectations about what counts as cooperation surely should influence state behavior (along with a variety of other factors, such as a state's discount rate, etc.). Moreover, Verdier and Voeten's point is not merely that cooperation may unravel in the future, but rather that it will do so because what counts as cooperation - the content of a legal rule-may change in response to violations. In this way, Verdier and Voeten move beyond standard two-by-two games that model international cooperation as a binary choice. Rather, when a state takes a precedential act, such as engaging in state practice in relation to a customary norm or engaging in treaty interpretation, it must be mindful of the act's lawmaking consequences. As Jeffrey Dunoff, Steven Ratner, and David Wippman describe the dynamic, "[b]ecause any outrageous or illegal claims or acts government officials make or take will erode a legal norm and create precedents that another state might in the future against their state, governments will restrain their behavior to conform to international law." 5

My contentions here are that the same basic dynamic applies to treaties, and that insights from this treaty dynamic can in turn inform the analysis of CIL that Verdier and Voeten present. I am by no means the first to make such an argument, but it is an important argument for three reasons.

First, we live in an age of codification. The customary lawmaking process remains distinct from the treatymaking process. Arguments about how CIL is implemented and enforced in the modern world, however, must grapple with the fact that many if not most customary rules are also contained in treaties. They are therefore subject both to treaty-based enforcement strategies, such as dispute resolution, as well as rules on CIL.

Second, the efficacy of enforcement strategies - and especially whether direct reciprocity can support compliance with a rule-depends mostly on the structure of the cooperative problem, not on whether the rule is a customary or treaty rule. Direct reciprocity can support compliance with legal rules in situations in which reciprocal non-compliance can be targeted at a violating state. It is not useful when the costs of reciprocal non-compliance are dispersed. As a counterpoint to Verdier and Voeten's claim that direct reciprocity cannot support compliance with CIL, I offer a number of examples of ways in which states can and do preserve their ability to use direct reciprocity to discipline violations of CIL. I also give examples of treaties that cannot be supported by direct reciprocity.

Third, violations and subsequent practice play an important role in negotiating and implementing treaties as well as custom. The chief difference between "bare", i.e., uncodified, custom and treaties is in how these rules are negotiated. Bare customary rules are negotiated, even if tacitly, through a series of claims and counterclaims about what custom requires. These claims are, however, decentralized. Unlike custom, negotiating international agreements is a more centralized and defined process. It therefore permits the use of a series of lawmaking devices unavailable in the customary context-for example, the use of exclusion, agenda control, and multi-issue bargaining.

\section{Codification}

Joel Trachtman has recently argued ${ }^{6}$ that the vast majority of customary rules have now been codified. Even if this claim is overstated, however, and many customary rules continue uncodified, the fact remains that codification has significantly narrowed the institutional gap between CIL and treaties. For example,

5 Jeffrey L. Dunoff, Steven R. Ratner, \& David Wippman, International Law: Norms, Actors, Process: A ProblemORIENTED APPROACH 31 (3d ed. 2010) (discussing the work of Georges Scelle).

${ }^{6}$ Joel P. Trachtman, The Obsolescence of Customary International Law (working paper) (Oct. 21, 2014). 
investment treaty tribunals regularly adjudicate CIL pertaining to investment. Likewise, much of the customary international law of human rights is subject to the reporting and monitoring mechanisms established by human rights treaties. Codification thus means that many customary rules can in fact be enforced as treaty rules.

This is not by any means to say that all of custom is subject to monitoring and dispute resolution. But many treaties also do not include robust, if any, monitoring or dispute resolution provisions. Nor do I intend to argue that codification has made custom obsolete. On the contrary, as I have argued elsewhere, ${ }^{7} \mathrm{I}$ believe that custom continues to serve an important function in the age of codification. Custom, because it does not require express state consent, can be used to create rules binding on holdout states. Codification can aid this process by committing groups of states to a particular view of what a generally applicable custom requires. The customary international law process can also serve other important functions, such as developing aspirational norms for the international system.

But a general argument about how customary rules lack the enforcement tools available to treaties has something of a historic feel-it may tell us about the way the world was, but absent an analysis of the role of codification, it tells us little about how custom works today. ${ }^{8}$ Put differently, we need to do away with the notion that "treaties and custom interact gingerly, each disturbing the other only after appropriate deliberation and development." While we have two different lawmaking processes, they often work in tandem to produce legal rules that have a basis in both custom and treaties. Moreover, this overlap means that today many customary norms can be contested and enforced through either or both processes.

\section{Reciprocity}

Nor, with respect to enforcement, are the techniques available so radically different. Verdier and Voeten's most controversial claim is that tit-for-tat reciprocity does not support compliance with customary rules. This argument flies in the face of the conventional wisdom, which suggests that in many areas dominated by custom, reciprocity and retaliation ${ }^{10}$ have been effective at sustaining cooperation. Whether tit-for-tat reciprocity can support compliance depends on whether states can target reciprocal non-compliance at violators. Put differently, are states able to adopt policies that are state-specific, or must they adopt a single policy with respect to other nations? Whether a rule is treaty or custom does not necessarily influence this aspect of the rule. Some reciprocity-based rules are custom, some are treaties. In the age of codification, many are both.

Examples of state policies explicitly authorizing state-specific tit-for-tat reciprocity to enforce CIL norms are numerous. Diplomatic law provides an obvious example. Despite its status as CIL, and thus the fact that it applies to all states, governments nevertheless can and do distinguish between the privileges and immunities provided to individual foreign missions. That is, the fact that diplomatic law applies to everyone has nothing to do with a state's ability to withdraw benefits under the rules from individual states. For example, the U.S. Foreign Missions Act (FMA), which governs the extension of benefits to diplomatic and consular missions, expressly authorizes the extension of benefits "on the basis of reciprocity." Indeed, in passing the FMA, Congress declared that " $[\mathrm{t}]$ he treatment to be accorded to a foreign mission in the United States shall be determined by the Secretary [of State] after due consideration of the benefits, privileges, and immunities provided to missions of the United States in the country or territory represented by that foreign mission."11

7 Timothy Meyer, Codifying Custom, 160 U. PA. L. Rev. 995 (2012).

8 Anthea Roberts, Traditional and Modern Approaches to Customary International Law: A Reconciliation, 95 AJIL 757 (2001).

${ }^{9}$ Meyer, supra note 7 .

${ }^{10}$ Ingrid Wuerth, Pinochet's Legacy Reassessed, 106 AJIL 731 (2012).

${ }^{11}$ Foreign Missions Act, 22 U.S.C. SS 4301-4316 (2001). 
The United Kingdom's laws are even more explicit. The 1964 Diplomatic Privileges ${ }^{12}$ Act provides expressly that customary diplomatic law rules codified in the Vienna Convention on Diplomatic Relations shall have the force of law in the United Kingdom, subject to the British government's authority to restrict individual state's privileges on the basis of reciprocity. In other words, the United States and the United Kingdom implement their treaty and CIL obligations with respect to diplomatic and consular law on the basis of reciprocity.

The immunity of foreign states — drawing on their prior work, ${ }^{13}$ the example that Verdier and Voeten lean on most for the proposition that states do not use reciprocity to enforce CIL norms-can instead be understood as another area in which states regularly preserve their ability to use reciprocity to sanction noncompliance. For example, the UK State Immunity Act of 1978 codifies, inter alia, the theory of restrictive immunity. It also provides an exception to the immunities it confers: "[i]f it appears to Her Majesty that the immunities and privileges conferred by this Part of this Act in relation to any State exceed those accorded by the law of that State in relation to the United Kingdom . . . Her Majesty may . . p provide for restricting ... those privileges and immunities to such extent as appears to Her Majesty appropriate."14 Similar provisions providing for state-specific reciprocal treatment appear in the state immunity acts of Australia (Section 42); ${ }^{15}$ Canada (Section 15);16 Pakistan (Section 16);17 Singapore (Section 17);18 and South Africa (Section 16). ${ }^{19}$ China's policy on sovereign immunity, formally one of the last holdouts for absolute immunity, expressly reserves the right ${ }^{20}$ to curtail foreign state's immunity on the basis of reciprocity. Nor does this authority to tailor immunity as applied go unexercised. In 199721 Canada restricted the sovereign immunity of the United States in Canadian courts upon a determination that the U.S. Foreign Sovereign Immunities Act did not afford Canada the same breadth of immunities that the Canadian State Immunity Act afforded the United States. Although one might expect reciprocal diplomatic negotiations to occur largely out of public view, Verdier and Voeten ${ }^{22}$ discuss other examples of state policies that provide a place for direct reciprocity, including Soviet and Chilean laws and a Polish practice of applying direct reciprocity through courts.

On the other hand, many legal rules, including treaty obligations, cannot be supported by tit-for-tat reciprocity, at least in the same issue area. Reciprocity cannot, for example, support compliance in the human rights context. If North Korea violates its human rights obligations, the United States cannot effectively punish North Korea by violating American human rights obligations. In case the practical difficulties with such a strategy are not determinative, Article 61 of the Vienna Convention on the Law of Treaties (VCLT) provides that states may not terminate or suspend the operation of a human rights treaty in response to a breach. Likewise, the European Union cannot use reciprocity to punish only Japan for failing to meet it greenhouse gas emissions reductions under the Kyoto Protocol. The European Union can either change its own climate policies, affecting the whole world, or not.

12 Diplomatic Privileges Act, 1964, c.81 (U.K.).

13 Pierre-Hugues Verdier \& Erik Voeten, How Does Customary International Law Change? The Case of State Immunity, 59 INT'L STUDIES Q. 209 (2015).

${ }^{14}$ State Immunity Act 1978, c.33 (U.K.).

${ }^{15}$ Foreign States Immunities Act 1985 (Cth), s.42 (Austl.).

16 State Immunity Act, R.S.C. 1985, c. S-18, s.15 (Can.).

17 State Immunity Ordinance, No. 16 of 1981 (Pak.).

${ }^{18}$ State Immunity Act 1979 , c. 313 , s.17 (Sing.).

${ }^{19}$ Foreign States Immunities Act 87 of 1981, $\int 16$ (S. Afr.).

${ }^{20}$ Dahai QI, State Immunity, China and Its Shifting Position, 7(2) CHI. J. INT’L L. 307 (2008).

${ }^{21}$ Order Restricting Certain Immunity in Relation to the United States, SOR/97-121 (State Immunity Act) (Can.).

22 Verdier and Voeten, supra note 13. 
In short, whether reciprocity can function as an enforcement strategy depends on whether states can target reciprocal exceptions to a general policy at specific states. It does not depend on whether the rule is custom or treaty-based.

\section{Negotiating International Law}

Although treaties and modern custom are not so dramatically different in how they are enforced, they do remain distinct lawmaking processes. Normally, the key difference is thought to be the role of practice versus express negotiation. Verdier and Voeten, who argue that " $[\mathrm{t}]$ reaties are generally the result of bargaining processes [while] CIL evolves through practice" (p.410), are among the great majority of scholars in noting such an alleged distinction. But the role of state practice in differentiating custom from treaties is overstated. State practice plays an important role in treaty interpretation and implementation, as required by VCLT Art. 31(3). As a testament to the importance of state practice to treaty interpretation, the International Law Commission is currently studying the role of subsequent practice ${ }^{23}$ on treaty interpretation (at the same time, perhaps coincidentally, that it is studying CIL. ${ }^{24}$

Moreover, as Michael Glennon has argued,25 "excessive violation of a rule, whether embodied in custom or treaty, causes the rule to be replaced by another rule." (emphasis added). Put differently, unilateral noncompliance, or more generally lawful non-participation such as through exit, is a technique used to spur renegotiation ${ }^{26}$ of both customary rules and treaty rules. Monica Hakimi has described ${ }^{27}$ how states may use "unfriendly unilateralism" as a lawmaking technique. In principle, the same concern that Verdier and Voeten raise about non-compliance with customary norms-that ordinary "cheating" will be taken for a jurisgenerative act—should apply to unilateral non-compliance with international agreements.

Nor is the difference between treaties and custom that the former is negotiated and the latter not. As Harlan Cohen has argued, customary rules are frequently negotiated. ${ }^{28}$ The extension of coastal jurisdiction illustrates the point. Beginning after the Second World War, a number of states began claiming that the territorial sea extended beyond three miles. Others refused to recognize these claims. While we can characterize these claims as "practice," they might just as reasonably be characterized as "offers" and "counteroffers." That is, they are public statements about how states interpret the law to which other states respond. States frequently blend this process of making claims and counterclaims with express written agreements that coordinate and solidify their position on custom. For example, Latin American countries used the 1952 Santiago Declaration on the Maritime Zone and the 1970 Montevideo Declaration on the Law of the Sea to establish their position on coastal state jurisdiction. Other nations then responded as the rules on coastal state jurisdiction solidified.

Rather than practice versus negotiation, the central distinction between custom and treaties is the manner in which each is negotiated. Customary rules are negotiated in a more decentralized way than are agreements. This decentralization changes the bargaining over CIL rules. As Laurence Helfer and Ingrid Wuerth have argued, states have a harder time engaging each other on the content of a customary rule at a single time,

23 InTERNATIONAL LAW COMMISSION, TREATIES OVER TIME/SUBSEQUENT AGREEMENTS AND SUBSEQUENT PRACTICE IN RELATION TO INTERPRETATION OF TREATIES (ANALYTICAL GUIDE) (2012).

${ }^{24}$ INTERNATIONAL LAW COMMISSION, FORMATION AND EVIDENCE OF CUSTOMARY INTERNATIONAL LAW/IDENTIFICATION OF CUSTOMARY INTERNATIONAL LAW (ANALYTICAL GUIDE) (2013).

${ }_{25}$ Michael J. Glennon, How International Rules Die, 93 GEO. L.J. 939 (2005).

26 Timothy Meyer, Power, Exit Costs, and Renegotiation in International Law, 51 HARV. INT'L L.J. 2 (2010).

27 Monica Hakimi, Unfriendly Unilateralism, 55 HaRv. INT'L L.J. 2 (2014).

${ }^{28}$ Harlan G. Cohen, International Law's Erie Moment, 34 MicH. J. INT’L L. 249 (2013). 
precisely because-absent codification — they are not bargaining in a multilateral forum ${ }^{29}$ with multiple states present and subject to agreed procedural rules. Likewise, states have a difficult time engaging in multi-issue bargaining in the CIL context. It is difficult in the bare CIL context, for example, for a state to convey to other states that it will acquiesce to the creation of CIL rules extending the territorial sea beyond three miles in exchange for concessions on the right of passage through the exclusive economic zone. Treaty negotiations solve this problem and, by packaging a set of legal rules together, create a credible commitment device ${ }^{30}$ that allows state to simultaneously pass multi-issue bargains. Treaty negotiations also allow states to use exclusion and agenda control techniques to drive outcomes. These techniques are unavailable for uncodified custom. While a state can be excluded from treaty negotiations, it cannot be prevented from making known its views on a customary rule that binds it. In sum, treaty-making facilitates a host of lawmaking techniques-agenda control, logrolling, vote trading - that are unavailable in the CIL context. We would thus expect treaty negotiations to produce systematically different results from what might emerge from a customary law process.

$* * * *$

Verdier and Voeten have made a very important contribution to the literature on international law and international relations. Their article highlights a key way in which non-compliance and lawmaking influence each other. It also tees up one of the core questions facing international lawyers today: in what ways do treaties and modern customary international law differ? The answer to that question can help us understand the contemporary role of custom and the relative advantages of each form of law.

${ }^{29}$ Laurence R. Helfer \& Ingrid Wuerth, Custom in the Age of Soft Law (working paper).

30 Timothy Meyer, From Contract to Legislation: The Logic of Modern International Lawmaking, 14(2) CHI. J. INT'L L. 559 (2014). 